\title{
Employment-GDP Elasticity in Argentina during 2004-2014
}

\author{
Ignacio Apella ${ }^{1}$ \\ ${ }^{1}$ World Bank, Social Protection and Labor Global Practice. \\ Correspondence: World Bank, Bouchard 547-29th (C1106ABG), Buenos Aires Country Office, Buenos Aires, Argentina.
}

Received: December 24, 2015

Accepted: January 12, 2016

Available online: February 26, 2016

doi:10.11114/ijsss.v4i3.1413

URL: http://dx.doi.org/10.11114/ijsss.v4i3.1413

\begin{abstract}
After the last economic crisis of 2001-2002, Argentina's economy showed significant signs of recovery, with average GDP growth rates of 9\%. Similarly, there was a complete reversal of the 90s' negative trend in employment rate. The objective of this paper is to estimate the employment-GDP elasticity in Argentina during the period 2004-2014, using a vector model with error correction mechanism for GDP, employment and average working hours per week. The results suggest the existence of a long-run relationship between employment and GDP, with an employment-GDP elasticity of 0.29 . However, the estimation rejects the hypothesis of a short-run relationship between both variables. Indeed, it appears that in a cyclical shock on GDP, employment remains inelastic, while the number of working hours is the adjustment variable. This result shows that firms find it more efficient to make adjustments in the amount of working hours during economic cycles instead of reorganizing the combination of productive factors.
\end{abstract}

Keywords: Elasticity, Employment, Labor Market

\section{Introduction}

The issues related to the labor market, both from an economic and public policy point of view, have always been focused on one perspective: the supply side. Initiatives such as lifelong learning programs, internships for younger people, unemployment insurances, and development of micro-entrepreneurs, are part of a broader set of policies designed to improve the employability - ability to enter the labor market - of the economically active population, particularly for those who find it more difficult to find a job. In Argentina, the Ministry of Labor, Employment and Social Security (MTEySS) has implemented a wide range of programs in this sense, such as the Employment and Training Insurance, Life Long Learning Program, Self-managed Work Program, Young with More and Better Jobs, among others.

However, the results obtained with these initiatives, in term of an increase of employment rate, depend not only on the operational capacity of the institutions responsible for their management and implementation, but also, and more importantly, on the ability of the labor demand to absorb the labor force. In other words, active labor market policies, rather than generating an increase in the employment rate, offer equal opportunities among the labor force.

One indicator that helps to understand the conditions that the public policy has to face in the labor market is the employment-product elasticity. This indicator measures the change in employment induced by changes in the Gross Development Product (GDP). Therefore, the elasticity of employment seeks to capture the reaction of the labor market to changes in macroeconomic conditions (represented by GDP growth). In this sense, the demand for labor is associated with economic growth, given that it constitutes one of the factors included in the production function.

The employment-GDP elasticity is a relevant indicator in the context of Argentina, as the last decade has shown a steady economic growth after one of the most severe economic, political and social crisis in the country. In 2002, the economic recession was highly alarming. According to data from the Ministry of Economy and Public Finance, GDP presented a decline of nearly $12 \%$ and the employment rate decreased to $32 \%$ of the population, one of its lowest levels. After that, Argentina's economy began to show signs of a rapid recovery, as a result of the change in the relative prices in favor of tradable goods. Between the first quarter of 2004 and the fourth quarter of 2007, economic growth had an annual average of around 9\%. During the years 2008 and 2009 the growth rate shrank to an average of $2 \%$ per year due to the international financial crisis, jumping back to the 9\% average growth rate in 2010 and 2011. In 2012 the economy returned to a path of economic slowdown, concluding 2014 with a fall in output $(-1 \%)$. In other words, in the last ten years Argentina's economy has maintained, with ups and downs, its path of economic growth. 
Employment has also showed remarkable signs of recovery in the last decade, growing an average of 3\% annually during the first half of the decade. Then, it remained constant during the years of economic downturn, and started growing again in 2010 and 2011. However, by the end of 2014, employment started to decrease.

In this context, the objective of this paper is to estimate the employment-GDP elasticity in Argentina during the period 2004-2014, and to understand the relationship between the dynamics of long and short run between these two variables. In the next section the theoretical framework of analysis is discussed. Section three presents the information source and develops the vector error correction model to be estimated. The fourth section describes the macroeconomic and employment context in Argentina during the period under study, while the fifth section presents the econometric results. Finally, some final remarks are discussed.

\section{Theoretical Framework}

The relationship between economic growth and employment has been the focus of study for many authors in the economic literature. Motivated by the pioneering work of Okun (1970), many authors have attempted to assess the response of employment to impulses of the product for different case studies (Prachowny, 1993; Caraiani, 2006; Leshoro, 2014; among others).

Okun (1970) suggests an inverse relationship between changes in GDP and changes in the unemployment rate, where GDP is regressed on unemployment; that is, real output growth was the exogenous (independent) variable and unemployment was the endogenous (dependent) variable (Okun, 1962, 1970). Based on a time series for the US economy since the second quarter of 1947 to the last quarter of 1960, the author predicted that a GDP growth of $3 \%$ led to a decrease in unemployment by $1 \%$.

Based on this original development it is possible to propose a similar relationship between the level of employment as the dependent variable, and GDP, as suggested by some authors (Pini, 1997; Baker and Schmitt, 1999; Osmani 2006; Leshoro, 2014; among others).

An appropriate indicator for evaluating the response of employment to changes in GDP is the employment-product elasticity. This is defined as the percentage change in the number of employed people relative to a percentage change in GDP. This indicator is a key parameter, not only in the field of macroeconomics but also in labor economics. Although there is a general agreement on the coefficient's definition and its significance - both theoretically and from the perspective of a public policy maker - there are many methods for its estimation ranging from the very simple to the relatively more complex.

In general terms, the calculation can be performed through two methods. The first one is the quantification of the arc elasticity of employment, defined as follows:

$$
\varepsilon_{t}=\left(\frac{\left(E_{t}-E_{t-1}\right) / E_{t-1}}{G D P_{t}-G D P_{t-1} / G D P_{t-1}}\right)=\frac{\Delta E_{t}}{\Delta G D P_{t}} \frac{G D P_{t}}{E_{t}}
$$

Where:

$E_{t}$ is the employment in $\mathrm{t}$

$E_{0}$ is the employment in 0

$\Delta E_{t}$ is the variation of the employment between $\mathrm{t}$ and $\mathrm{t}-1$

$\Delta G D P_{t}$ is the variation of the GDP between $\mathrm{t}$ and $\mathrm{t}-1$

The numerator of (1) simply gives the percentage change in employment, while the denominator represents the percentage change in GDP. The formula of the employment-GDP elasticity is very simple and easy to apply. By having employment and output data in two different moments of time, the use of equation (1) only allows quantification of the arc elasticity (elasticity between two different moments of time) and not the point elasticity.

The second technique is the point elasticity of employment, which uses econometric technique and which is the focus of this study. However, there is no consensus in the literature about the most accurate method to make this estimation because the shape and model depend largely on the properties of the data series and on the economic context of each country which could allow other exogenous variables from the labor market and the economy as whole to induce employment rate changes.

Pini (1997) estimated employment-GDP elasticities for a number of OECD countries and the results showed higher values in the cases of Germany and Japan, while for the cases of France and Sweden this coefficient was lower. Conversely, negative values of the employment elasticity were found in the case of Italy and Sweden.

For the case of the European Union, Marelli and Signorelli (2010) found a negative relationship between employment 
and GDP. That is, the high employment growth resulted in slower economic growth.

An interesting line of research was introduced by Prachowny (1993). He introduced the possibility of estimating the employment elasticity with the help of a production function. In this sense, we noted that changes in weekly working hours and the use of capital, in addition to variations in the level of employment, have significant influences on changes in the product. Similarly, and for the Uruguayan case, Amarante (2000) proposed the estimation of the production function (GDP) depending on working hours, the number of employed people and the capital endowment. The argument behind this specification is that the firm can be modeled as a rational entity, maximizing profits, in which the number of working hours is the result of the optimization process. For them, extra hours can be highly productive and efficient, and this could explain why the reduction in the number of jobs has not been accompanied by a reduction in the working hours.

However, the estimation of the production function to indirectly calculate the employment elasticity requires some precautions. What appears to be a rather simple algebraic manipulation of the relationship between employment and GDP represents poor econometrics in practice, and it can have important implications for the interpretation of subsequent results. This is due to the presence of random errors in the estimation. Only in the case where the correlation between both variables is equal to one, will the regression of GDP on employment have a slope coefficient equal to the reciprocal of the slope coefficient in the regression of employment on GDP.

For the particular case of Argentina, Müller and Lavopa (2006) explore the determinants of employment in Argentina, using a disaggregated perspective by sector. Their argument is based on the need to have inputs to develop an active policy to absorb unemployment, after the strong increase of this variable in the $90 \mathrm{~s}$.

To do this, the authors propose a model where the logarithm of employment is regressed against the logarithm of GDP, both global and sectorial for the period between 1995 and 2005. The values of employment elasticity found by the authors suggest a significant variability by activity sector. For the whole economy employment elasticity is 0.6 , sectorial values range from 0.6 to more than 1 , and $60 \%$ of the sectors have significant employment elasticities. While this methodology allows for direct elasticity coefficients associated with the long run relationship of both variables, it does not consider the residual effects of the dependent variables or the effects from other labor market variables.

In this sense, Prachowny (1993) suggests that changes in the number of working hours and capital utilization could also affect the level of employment/unemployment, since various factors may change with the employment rate and therefore the estimated coefficient captures the combined effect of all influences on the product.

It is necessary to consider two observations. The first one is associated with the relationship between employment and GDP, and, in particular, it is embodied in the issue of the two-way relationship between employment and output. From the perspective of an economy-wide production function, the use of labor and complementary factors of production generates national output or GDP, so the faster the growth of labor, ceteris paribus, the faster the growth of output. As a consequence, the notion of employment elasticity focuses only on the demand side of the relationship (with GDP acting as a representation for aggregate demand) and ignores the supply side (the output-creating effect of labor utilization).

On the other hand, the notion of employment elasticity is valid for a given state of technology and knowledge. As technology changes and knowledge about 'best-practice' production processes change, it can make a given percentage growth of GDP more or less employment intensive. Furthermore, the notion of employment elasticity is 'endogenous' to the policy regime. A given policy regime could be more or less conducive to employment growth. For example, existing policy initiatives could encourage labor- intensive technology or they could impart a capital bias in production processes. The clear implication is that the elasticity of employment is not really an 'exogenous' variable.

Finally, a further comment is due on the indifferent use of employment and unemployment in this kind of estimation motivated by Okun's law. It is not indifferent to estimate Okun's coefficient using the level of employment or unemployment, given that there are behaviors that could affect both indicators in different ways, by means of the "registration" and "despair" effect. In times of recession some unemployed people, discouraged by the slim possibilities of finding a job, stop seeking employment and thus become part of the inactive population, lowering the unemployment rate. In times of expansion the opposite happens, as there will be inactive people who, given the improvement of job-finding prospects, will start actively seeking employment again, thus becoming part of the unemployed population. Consequently, if a percentage of these people end up finding a job, the unemployment rate will not fall proportionally to the increase in the level of employment.

Therefore, an alternative to minimize such effects is to analyze the level of employment in its absolute values (that is, the number of employed people) and not on its rates. Indeed, a certain amount of labor is needed to generate a given level of product. 


\section{Data and Methodology}

\subsection{Data}

Quarterly data over the period 2004 to 2014 is used in this paper. Employment is measured in absolute values in thousands of workers, real GDP at 2004 prices is measured in millions of Argentinean pesos. The data for GDP and employment are taken from the National Institute of Statistics and Census (INDEC). The average working hours per week were calculated based on the Permanent Household Survey relieved by INDEC.

\subsection{Methodology}

The proposed econometric model for estimating employment-GDP elasticity is a model with Vector Error Correction (VEC) which starts off a long run equilibrium relationship between the variables. It is presented as a double-log multivariate model in equation 2 below:

$$
\log E_{t}=\alpha_{0, t}+\alpha_{1, t} \log G D P_{t}+\alpha_{2, t} \log H_{t}+\varepsilon_{t}
$$

Where:
$E_{t}$ is the employment in $\mathrm{t}$
$H_{t}$ is the working hour per week in $\mathrm{t}$
$\varepsilon_{t}$ is the error term
$\alpha^{\prime} s$ are the coefficients, which are interpreted as elasticities

Table 1 shows the different ways of interpreting the coefficients estimated for employment elasticity.

Table 1. Interpretation of employment elasticity

\begin{tabular}{c|l}
\hline Employment elasticity & GDP \\
\hline$\alpha_{1, t}<0$ & $\begin{array}{l}\text { (-) employment growth } \\
(+) \text { productivity growth }\end{array}$ \\
\hline $0 \leq \alpha_{1, t} \leq 1$ & $\begin{array}{l}\text { (+) employment growth } \\
(+) \text { productivity growth }\end{array}$ \\
\hline$\alpha_{1, t} \geq 1$ & $\begin{array}{l}\text { (+) employment growth } \\
\text { (-) productivity growth }\end{array}$ \\
\hline
\end{tabular}

Source: Leshoro (2014)

The table shows that in an economy with a positive GDP growth, negative employment elasticity means that the economy is experiencing negative employment growth and positive productivity growth. On the other hand, in an economy with a negative GDP growth, negative employment elasticity corresponds with positive employment growth and negative productivity growth. The inverse is true for an economy with a positive and a negative GDP growth, respectively, when employment elasticity is greater than one. However, if the employment elasticity lies between zero and one, an economy with positive GDP growth will experience positive employment and productivity growth. This is the ideal position for any economy with increases in employment coupled with productivity gains.

In order to avoid spurious regression results, we need to test the stationarity of the time series, which means that the mean and the variance of the series are constant over time and that the null hypothesis states that the series has a unit root. For example, given:

$$
E_{t}=\rho E_{t-1}+\varepsilon_{t}
$$

Where $\varepsilon_{t}$ is the stochastic error term, and $E_{t-1}$ is one period lag of the employment variable. If $\rho$ is equal to 1 , then the series are not stationary. The same test is necessary for the rest of the variables, $G D P_{t}$, and $H_{t}$.

There are at least two ways to model stationary series, the first is to work with their differences. Another alternative is to corroborate the existence of cointegration between the variables involved and work with their values expressed in their levels. The first of these possibilities captures the short-run relationship existing between the variables involved, while the second seeks to explain its long-run equilibrium relationship.

Cointegration is a linear combination of two or more time-series that have the same order of integration but are not stationary. If two or more variables are cointegrated, it shows that there is a long-run relationship between them. The 
long-run equation is therefore as shown in equation (2).

In general, most time series have unit roots and therefore are integrated of order one I(1). Thus, cointegration between theses time-series is cointegrated of order one. However, we have to consider the possibility that one of these series could have an order of integration higher than one, for example of order two I(2). Although there could be a mix of orders of integrations, that is I(1) and I(2), these variables can break down such that there is still cointegration.

Given that the objective of this paper is to explain the long-run relationship between employment and GDP, if the series are stationary, the possibility of working with their differences is not a viable option because, as it was mentioned before, this procedure captures the short-run relationship. Therefore, the variables should be at their levels and then identify the existence of cointegration.

However, given the possibility that employment can be affected by short-run shocks, we need to develop an equation which considers together both types of variables, at their level and differences values. This is commonly known as a vector model with error correction mechanism (VEC) (Enders, 2009). In this sense, the VEC corrects imbalances of the variables between the short and long run.

$$
\Delta \log \mathrm{E}_{\mathrm{t}}=\varphi_{0} \varepsilon_{\mathrm{t}-1}+\alpha_{0, \mathrm{t}}+\sum_{\mathrm{i}=1}^{\mathrm{n}} \alpha_{1, \mathrm{i}} \Delta \log G D P_{\mathrm{t}-\mathrm{i}}+\sum_{\mathrm{i}=1}^{\mathrm{n}} \alpha_{2, \mathrm{i}} \Delta \log \mathrm{H}_{\mathrm{t}-\mathrm{i}}+\sum_{\mathrm{i}=1}^{\mathrm{n}} \alpha_{3, \mathrm{i}} \Delta \log \mathrm{E}_{\mathrm{t}-\mathrm{i}}+\mu_{\mathrm{t}}
$$

Where $\Delta$ denotes the first difference of the variables, $\mu_{\mathrm{t}}$ is the error term, $\varepsilon_{\mathrm{t}-1}$ is one period lag of the error term obtained from the cointegration model in equation (2).

Results of the employment elasticity allow us to understand the history of the relationship between employment and growth in Argentina in the last 10 years, and they will be interpreted as correlation coefficient, rather than causality.

\section{Economic Growth and Employment in Argentina between 2004 and 2014}

The main stylized facts of the labor market in the 2000s show a complete reversal of the negative trends observed in the past decade. In fact, after a sharp deterioration of working conditions as a result of the 2001-2002 crisis, employment showed a very fast recovery, specially addressed by the full-time employment.

This change was driven by the configuration of a radical new macroeconomic scenario, based on a competitive and stable exchange rate during the first years post-crisis. Figure 1 presents the evolution of GDP, employment rate and the average working hours per week, between the first quarter of 2004 and third quarter of 2014.

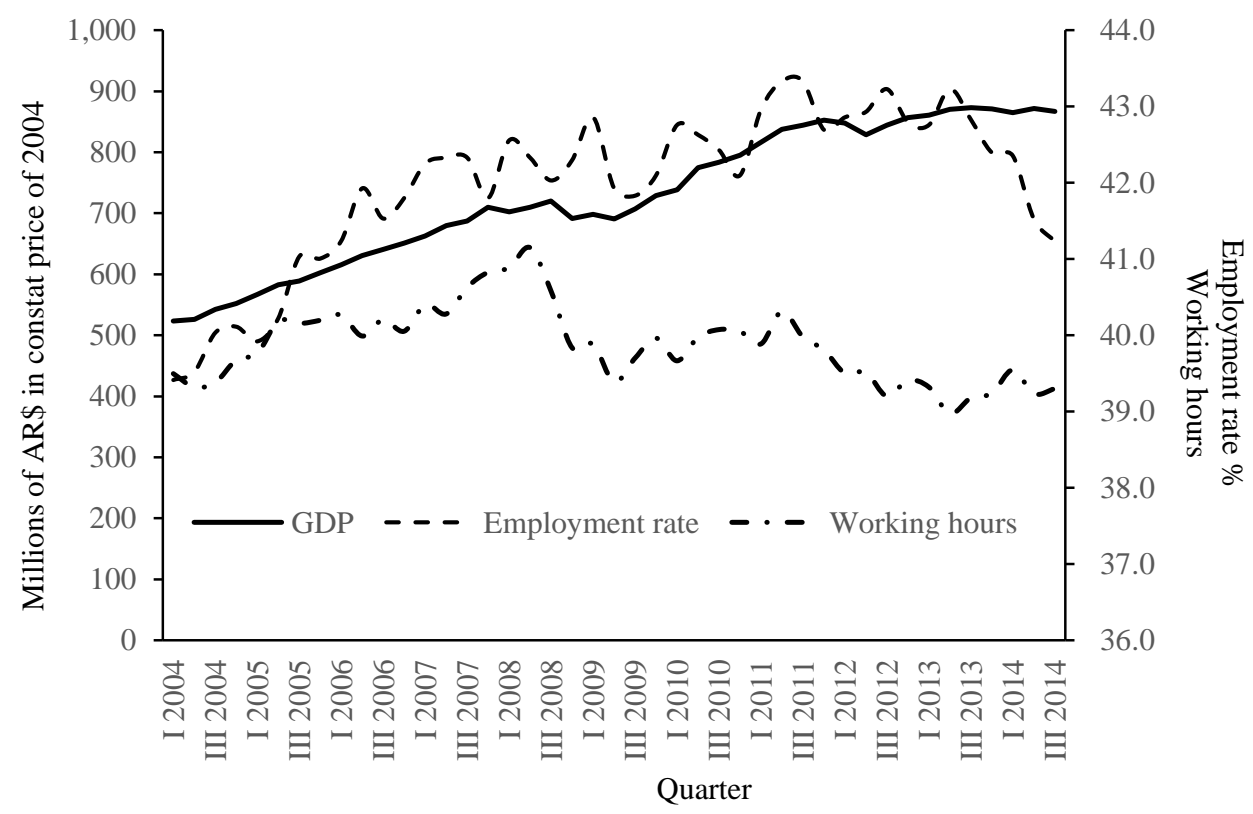

Figure 1. GDP, employment rate and working hours per week. I quarter 2004 - III quarter 2014

Source: own elaboration based on INDEC

During the first part of the decade following de 2001-2002 crisis, Argentina's economy showed signs of a fast and significant recovery. Indeed, between the first quarter of 2004 and the fourth quarter of 2007, average economic growth was around $9 \%$. 
The change in relative prices after the devaluation had a very favorable impact on the international tradable goods. On the one hand, the profitability of firms in these industries was recomposed. Furthermore, the relative increase of the imported goods prices allowed a change in the composition of aggregate demand for goods produced within the country. This economic recovery in turn induced an improvement in the level of employment.

Since 2003, we observed a period where the level of employment showed a quick recovery. According to Damill et al. (2011) this process has been characterized by a high creation of new jobs in the private sector. Between 2004 and 2007 the rate of employment increased from $39.4 \%$ to $42.5 \%$.

In 2008 the economy started to show signs of a slowdown. The international financial crisis coupled with falling commodity prices led to a contraction in economic activity. During 2008 and 2009 the average growth shrank to $2 \%$.

However, Argentina was in a relatively strong position to withstand the impact of the crisis. Following Damill and Frenkel (2013), the country faced the international crisis with a substantial quantity of reserves and surplus in the current and financial accounts, due to the previous exchange rate policy and the accumulation of reserves. Additionally, the country's exports were concentrated in primary goods, whose prices suffered only a moderate decline and maintained better prospects than other commodities.

Those two years showed some stagnation in the employment rate. Furthermore, the first two quarters of 2009 showed a decrease in the number of employed people. However, the negative effect of the crisis on labor demand was not as significant as it had been in previous crises. According to Damill et al. (2011), some of the measures taken by the Government to avoid layoffs and preserve jobs in the private sector, such as wage subsidies and increase in public employment, contributed to this result.

After the international financial crisis, in 2010 and 2011, the economy returned to its expansion path, growing on an annual average of $9 \%$. However, in 2012 signs of exhaustion were observed with a slowdown in the third quarter of 2014 and a $1 \%$ fall in output. This is correlated with the level of employment, which showed a steady decline since 2013 , reaching $41.2 \%$ in the third quarter of 2014.

Finally, throughout the period under study, the average number of working hours per week was 39.8 hours. This implies an average working day of eight hours per day. However, some variability is identified. During 2004 and the fourth quarter of 2007, a significant increase in working hours was observed, following the upward cycle in the economy. In the last quarter of 2013 the maximum value (41 hours) is reached. Thereafter, and on par with the economic slowdown, this indicator stabilizes around the values of early 2004, although experiencing a jump in 2011. Figure 2 shows the quarterly arc elasticity of employment-GDP.

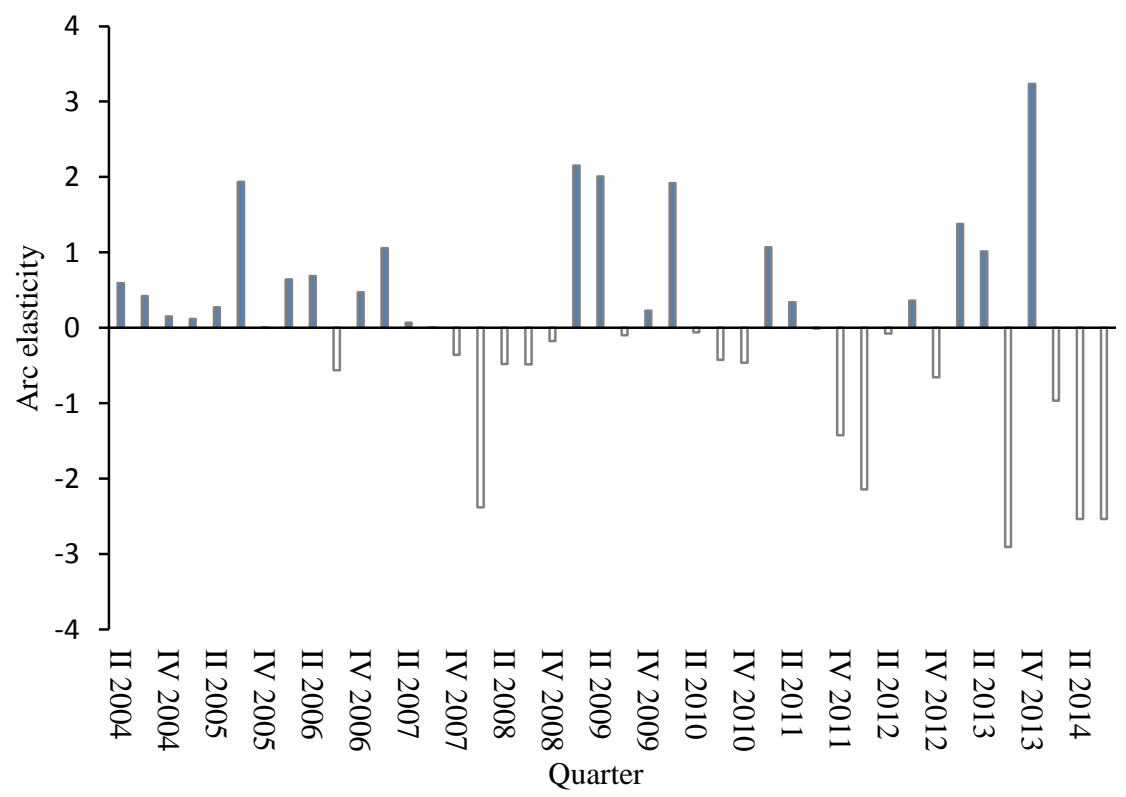

Figure 2. Arc-elasticity employment-GDP

Source: our own elaboration based on INDEC

The quarterly arc employment elasticities from equation (1) have a significant fluctuation during the period. Indeed, in 
some quarters elasticity is negative. It is clear that the level and trend of arc employment elasticity are not very useful for policy and even for follow up purposes.

\section{Econometric Results}

Figure 3 presents the time series of the logarithm of each variable used in this work, with seasonality, for the period under study. Observing the figures, it is possible to suggest that both the GDP and the employment series have a trend and do not present a stationary behavior. This is not the case for the average working hours per week.

Log Employment. I Quarter 2004 - III Quarter 2014

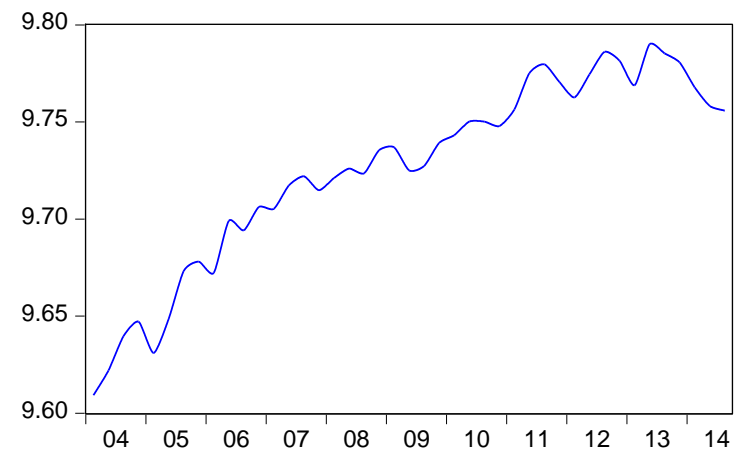

Log Working Hours. I Quarter 2004 - III Quarter 2014

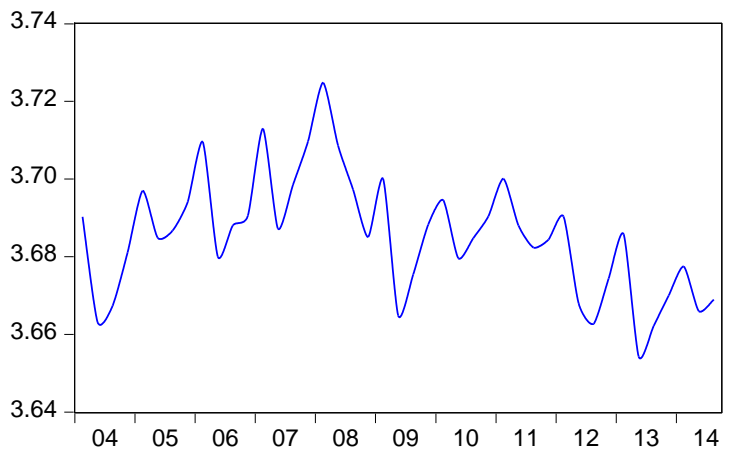

Log GDP. I Quarter 2004 - III Quarter 2014

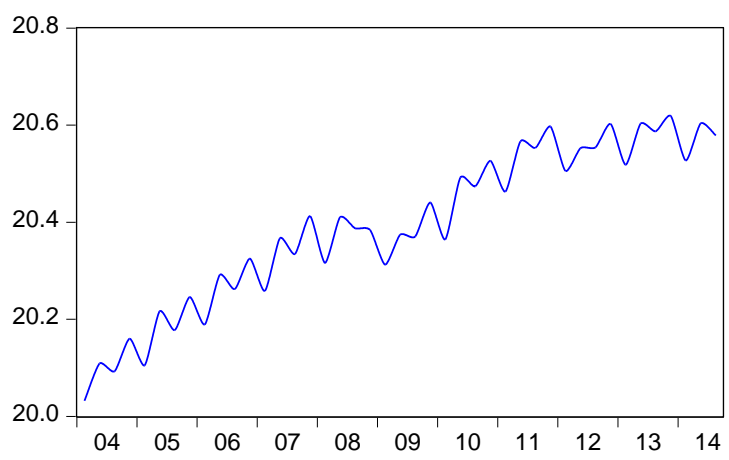

Figure 3. Main variables description

Source: own elaboration based on INDEC and EPH

The stationarity of the variables was tested using the "trend and intercept" (Table 2). None of the variables was found to be stationary at $5 \%$ level of significance. The dependent variable, employment, as well as the average working hours per week, are stationary after the first difference. Meanwhile, GDP is stationary in its first difference at $10 \%$ level of significance, and in its second difference at $1 \%$. This means that employment and the working hours are integrated of order 1, I (1), and GDP is integrated of order 2, I(2).

Table 2. Test of stationary: Augmented Dickey-Fuller

\begin{tabular}{llll}
\hline Variable & Level & 1st difference & 2nd difference \\
\hline Log E & -0.242244 & $-7.229013^{* * *}$ & n.a \\
Log GDP & -1.131637 & $-1.685301^{*}$ & $-28.57015^{* * *}$ \\
Log H & -2.404921 & $-8.82213^{* * *}$ & n.a \\
\hline
\end{tabular}

Source: our own elaboration

Significance at $* * * 1 \%, * * 5 \%, * * * 10 \%$

Critical values, Trend and Intercept: $1 \%=-4.211868 ; 5 \%=-3.529758 ; 10 \%=-3.196411$

Critical values 1st difference without Trend and Intercept: $1 \%=-2.622585 ; 5 \%=-1.949097 ; 10 \%=-1.611824$

Although there is a mix of orders of integrations, that is I (1) and I(2), these variables can be broken down so that there still is cointegration. Therefore, the test of cointegration was carried out and the result, as shown in Table 3, confirms that there is one cointegrating equation at a 5\% level of significance according to the Maximum Eigenvalue and Trace tests. 
Tabla 3. Test of cointegration

a) Unrestricted Cointegration Rank Test (Trace)

\begin{tabular}{lllll}
\hline Hypothesized No. of CE(s) & Eigenvalue & Trace Statistic & Critical Valu & Prob.** \\
\hline None* & 0.485148 & 39.51608 & 29.79707 & 0.0028 \\
At most 1 & 0.231774 & 13.62489 & 15.49471 & 0.0938 \\
At most 2 & 0.082117 & 3.341718 & 3.841466 & 0.0675 \\
\hline
\end{tabular}

Trace test indicates 1 cointegrating eqn(s) at the 0.05 level

b) Unrestricted Cointegration Rank Test (Maximum Eigenvalue)

\begin{tabular}{lllll}
\hline & & Max-Eigen & \\
Hypothesized No. of CE(s) & Eigenvalue & Statistic & Critical Value & Prob.** \\
\hline None* & 0.485148 & 25.89119 & 21.13162 & 0.0099 \\
At most 1 & 0.231774 & 10.28317 & 14.2646 & 0.194 \\
At most 2 & 0.082117 & 3.341718 & 3.841466 & 0.0675 \\
\hline
\end{tabular}

Max-eigenvalue test indicates 1 cointegrating eqn(s) at the 0.05 level

A general-to-specific method was adopted where the parsimonious model of ECM was first performed with four lag lengths as selected by the entire lag length criteria (See appendix). This lag length was not surprising because real economic variables take a long time to adjust to changes in the economy. The results of the specific model of the error correction model, which is the short-run dynamics of the long-run relationship among the variables, are reported in Table 4.

Table 4. Result of the employment elasticity of Argentina: 2004 - 2014 (Dependent variable - Employment) - Error Correction Mechanisim $\Delta \log E$

\begin{tabular}{llll}
\hline Variable & Coefficient & $\mathrm{SE}$ & $\mathrm{t}$-stat \\
\hline \multicolumn{1}{c}{$\varepsilon_{t-1}$} & -0.232941 & 0.23724 & -0.9819 \\
$\Delta \log \mathrm{E}_{\mathrm{t}-1}$ & 0.114243 & 0.25842 & 0.44209 \\
$\Delta \log \mathrm{Y}_{\mathrm{t}-1}$ & -0.032469 & 0.06969 & -0.46592 \\
$\Delta \log \mathrm{H}_{\mathrm{t}-1}$ & 0.04573 & 0.21655 & 0.21118 \\
$\Delta \log \mathrm{E}_{\mathrm{t}-2}$ & -0.259955 & 0.20353 & -1.27722 \\
$\Delta \log \mathrm{Y}_{\mathrm{t}-2}$ & 0.018953 & 0.0815 & 0.23255 \\
$\Delta \log \mathrm{H}_{\mathrm{t}-2}$ & 0.201731 & 0.17872 & 1.12877 \\
$\Delta \log \mathrm{E}_{\mathrm{t}-3}$ & 0.083366 & 0.2139 & 0.38974 \\
$\Delta \log \mathrm{Y}_{\mathrm{t}-3}$ & -0.036522 & 0.0709 & -0.51508 \\
$\Delta \log \mathrm{H}_{\mathrm{t}-3}$ & 0.16512 & 0.17847 & 0.92519 \\
Constant & 0.003828 & 0.00228 & $1.68208^{*}$ \\
\hline $\mathrm{R} 2$ & 0.356133 & & \\
\hline
\end{tabular}

*** Significant at $1 \%, * *$ at $5 \%, *$ at $10 \%$

With a very low explanatory power, the results do not suggest the existence of a short-run relationship between changes in output and employment levels. No lagged coefficient associated with the GDP variation is significant. Nor is there any significance in the estimated coefficients accompanying the variations in the number of working hours and employment levels.

In other words, it is possible to suggest that, in the short-run, variations in employment are not correlated with shocks on GDP. This phenomenon is associated with the existence of some rigidities in the labor market that protect the employment from cyclical fluctuations in the economy. Among these rigidities it is possible to mention not only the cost of firing workers but also that it could be more efficient for the firm to reduce the number of working hours per week shifts suspension. In fact, Table A.3 in the appendix presents the results obtained from the same VEC model using the logarithm of the number of working hours as dependent variable and the logarithm of GDP and employment as independent variables.

Beyond the cointegration relationship between the variables, the results support the hypothesis of the existence of a short-run dynamics between the average number of working hours and the GDP. An increase of $1 \%$ of GDP in t-1 affects the number of working hours by $25.3 \%$ ( 2 extra hours). Also, we observe that an increase of $1 \%$ of GDP in t-2 increases working hours per week by $24.5 \%$ in $\mathrm{t}$.

However, the working hours per week are negatively correlated with their value in $\mathrm{t}-2$, showing that this variable adjusts 
to itself. On the other hand, the coefficient of the error correction term of -0.19 indicates that once the long-run equation model is shocked, there will be a fast convergence to equilibrium with about $19 \%$ adjustment in the first quarter.

As it was corroborated by the cointegration test, there is a long-run relationship between employment and GDP, made explicit in equation 2. The results of this estimation are presented in Table 5.

Table 5. Estimation of the cointgration. 2004 - 2014

\begin{tabular}{llll}
\hline Variable & Coefficient & SE & t-stat \\
\hline $\log \mathrm{Y}_{\mathrm{t}}$ & $0.295136^{* * *}$ & 0.0129 & 22.87865 \\
$\log \mathrm{H}_{\mathrm{t}}$ & $0.275365^{* *}$ & 0.13772 & 1.999454 \\
Constant & $2.692293^{* * *}$ & 0.646197 & 4.166368 \\
\hline $\mathrm{R} 2$ & 0.933462 & & \\
Prob. F-stat & 0.000000 & & \\
\hline
\end{tabular}

$* * *$ Significant at $1 \%, * *$ at $5 \%, *$ at $10 \%$

With a very good fit regression, explaining $93.3 \%$ of total variance, all coefficients are jointly significant. The coefficient of the GDP is positive and significant at $1 \%$ as expected. In this sense, the long-run equilibrium relationship between both variables is 0.295 : an increase of $1 \%$ in GDP increases employment by $0.295 \%$.

This elasticity value suggests that there is a low capacity of demand to absorb labor supply, while sustained growth of $3.4 \%$ of GDP is needed for demand to absorb $1 \%$ of jobs offered.

\section{Conclusions}

After the last economic crisis of 2001-2002, Argentina's economy showed significant signs of recovery, with GDP growth rates that reached an average of $9 \%$. Similarly, there was a complete reversal of the 90s' negative trend in employment rate. Indeed, after a sharp deterioration of working conditions in 2001-2002, employment showed a rapid increase, specially addressed by full-time employment. This implied an annual average employment growth rate of $3 \%$ in the first half of the decade.

Through a vector model with error correction mechanism, employment-GDP elasticity was estimated considering both the long-run equilibrium relationship (cointegrating equation) and the short-run dynamics between the variables. The formulation of this model presents the relationship between employment, GDP and average working hours per week. The general idea is to get a better understanding of the type of relationship between employment and GDP, both in the short and long run.

Results suggest the existence of a long-run relationship between employment and GDP (cointegration equation) where employment-GDP elasticity is 0.29 . However, the estimation rejects the hypothesis of a short-run relationship between both variables. Indeed, it appears that in cyclical shocks on GDP, employment remains inelastic, while the number of working hours acts as adjustment variable. A 1\% GDP increase in t-1 affects the number of working hours by $25.3 \%$. This result implies a two hours per day increase in working hours. The weekly average of working hours is 40 hours.

This result implies that firms find it more efficient to make adjustments in the quantity of working hours during economic cycles instead of reorganizing the combination of productive factors. As a consequence, it can be argued that during economic upturns overtime work could be productive and efficient, and its suspension could be necessary during economic downturns.

\section{Acknowledgements}

Opinions are absolutely responsibility of mine and not of the Institution I represent. I would like to thank Pablo Jack for his cooperation on the preparation of this paper.

\section{References}

Ajilore, T., \& Yinusa, O. (2011). An analysis of employment intensity of sectoral output growth in Botswana. Southern African Business Review, 15(2), 26 - 42.

Baker, D., \& Schmitt, J. (1999). The macroeconomic roots of high unemployment: The impact of foreign growth Economic Policy Institute. Available: http://www.epinet.org

Blanchard, O., \& Quah, D. (1989). The Dynamic Effects of Aggregate Demand and Supply Disturbances. American Economic Review, 79, 655-673.

Damil, M., Frenkel, R., \& Maurizio, R. (2011). Macroeconomic Policy for Full and Productive Employment and Decent Work for All: An Analysis of the Argentine Experience. Employment Working Paper 109, International Labor Organization. 
Damil, M., \& Frenkel, R. (2013). La Econmomía Argentina Bajo los Kirchner: Una Historia de Dos Lustros, in Peruzzotti, E. \& Gervasoni, C. (eds.) La Década Kirchnerista. Editorial Sudamericana, Buenos Aires.

Enders, W. (2009). Applied Econometric Time Series. Wiley 3th edition.

Evans, G. W. (1989). Output and Unemployment Dynamics in the United States: 1950-1985, Journal of Applied Econometrics, 4, 213-238.

Gordon, R., \& Clark, P. (1984). Unemployment and Potential Output in the 1980's. Brooking Papers on Economic Activity, 15(2), 537-564.

Leshoro, T. (2014). Emprical Analysis of Employment Elasticity of Growth in Botswana. Mediterranean Journal of Social Sciences, 5(2), 171-179.

Marelli, E., \& Signorelli, M. (2010). Employment, productivity and models of growth in the EU. International Journal of Manpower, 31(7), 732-754.

Okun, A. (1970). Potential GDP: Its Measurement and Significance in Okun, A. (ed.), The Political Economy of Prosperity. Washington D. C.

Osmani, S. R. (2000). Employment Intensity of Asian Manufacturing: An Examination of Recent Trends. Paper prepared for the Asian Regional Bureau of the United Nations Development Programme (UNDP), New York.

Pini, P. (1997). Occupazione, tecnologia e crescita: modelli interpretativi ed eevidenze empiriche a livello macroeconómico Paper presented at Conference of Accademia Nazionale dei Lincei on 'Sviluppo tecnologico e disoccupazione: trasformazione della societa', Rome, 16-18.

Plosser, C., \& Schwert, W. (1979). Potential GNP: Its Measurement and Significance. A Dissenting Opinion. Journal of Monetary Economics, 10, 179-186.

Prachowny, M. (1993). Okun`s Law: Theoretical Foundations and Revised Estimates. Review of Economics and Statistics, 55, 331-336.

Romer, D. (2001). Advanced Macroeconomics. 2nd Edition. New York: McGraw Hill/Irwin.

Villaverde, J., \& Maza, A. (2009). The robustness of Okun's law in Spain, 1980 - 2004: Regional Evidence. Journal of Policy Modeling, 31(2), 289 - 297. 


\section{Appendix}

Table A.1. Lag leghnt selection

\begin{tabular}{lllllll}
\hline Lag & LogL & LR & FPE & AIC & SC & HQ \\
\hline 0 & 249.7709 & NA & $4.59 \mathrm{E}-10$ & -12.98794 & -12.85866 & -12.94194 \\
1 & 313.6843 & 114.3713 & $2.56 \mathrm{E}-11$ & -15.87812 & -15.36099 & -15.69413 \\
2 & 329.3514 & 25.56217 & $1.82 \mathrm{E}-11$ & -16.22902 & -15.32404 & -15.90704 \\
3 & 340.5871 & 16.55788 & $1.66 \mathrm{E}-11$ & -16.34669 & -15.05386 & -15.88671 \\
4 & 383.3908 & $56.32058^{*}$ & $2.94 \mathrm{e}-12^{*}$ & $-18.12583^{*}$ & $-16.44515^{*}$ & $-17.52786^{*}$ \\
5 & 390.6795 & 8.439618 & $3.49 \mathrm{E}-12$ & -18.03576 & -15.96723 & -17.2998 \\
\hline
\end{tabular}

LR: sequential modified LR test statistic (cada test al 5\%)

FPE: Final prediction error

AIC: Akaike information criterion

SC: Schwarz information criterion

HQ: Hannan-Quinn information criterion

Table A.2. Results of the diagnostic test - VEC

\begin{tabular}{ll}
\hline Test & p-value \\
\hline Normality test: Cholesky (Lutkepohl) & 0.6405 \\
Serial correlation: Breusch-Godfrey LM & 0.6448 \\
Heteroskedasticity test: Breusch-Pagan-Godfrey & 0.5919 \\
\hline
\end{tabular}

Table A.3. Result of the working hours equation of Argentina: 2004 - 2014 (Dependent variable working hours) - Error Correction Mechanisim $\Delta \log H$

\begin{tabular}{llll}
\hline Variable & Coefficient & $\mathrm{SE}$ & $\mathrm{t}$-stat \\
\hline$\varepsilon_{\mathrm{t}-1}$ & -0.198393 & 0.12125 & $-1.63625^{*}$ \\
$\Delta \log \mathrm{H}_{\mathrm{t}-1}$ & -0.221392 & 0.18441 & -1.20053 \\
$\Delta \log \mathrm{Y}_{\mathrm{t}-1}$ & 0.253164 & 0.05935 & $4.26596^{* * * *}$ \\
$\Delta \log \mathrm{E}_{\mathrm{t}-1}$ & -0.232088 & 0.22007 & -1.05462 \\
$\Delta \log \mathrm{H}_{\mathrm{t}-2}$ & -0.336554 & 0.1522 & $-2.21131^{* * *}$ \\
$\Delta \log \mathrm{Y}_{\mathrm{t}-2}$ & 0.245984 & 0.06941 & $3.54407^{* * * *}$ \\
$\Delta \log \mathrm{E}_{\mathrm{t}-2}$ & -0.266009 & 0.17333 & -1.53472 \\
$\Delta \log \mathrm{H}_{\mathrm{t}-3}$ & -0.146822 & 0.15199 & -0.96602 \\
$\Delta \log \mathrm{Y}_{\mathrm{t}-3}$ & 0.151273 & 0.06038 & $2.50524^{*}$ \\
$\Delta \log \mathrm{E}_{\mathrm{t}-3}$ & -0.111022 & 0.18216 & -0.60948 \\
$\mathrm{C}$ & -0.006317 & 0.00194 & $-3.2594^{* * *}$ \\
\hline $\mathrm{R} 2$ & 0.752484 & & \\
\hline
\end{tabular}

$* * *$ Significant at $1 \%, * *$ at $5 \%, *$ at $10 \%$

\section{(cc) EY}

This work is licensed under a Creative Commons Attribution 3.0 License. 